Report of Investigation 2017-2

\title{
REGIONAL TSUNAMI HAZARD ASSESSMENT FOR ANDREANOF ISLANDS, ALASKA
}

E.N. Suleimani, D.J. Nicolsky, R.D. Koehler, and J.B. Salisbury

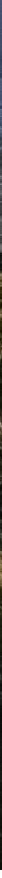

Published by

State of Alaska

Department of Natural Resources

Division of Geological \& Geophysical Surveys

2018

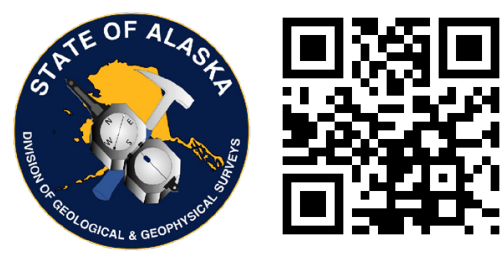


Cover Image. Looking east from Adak Island toward Kuluk Bay, the airport is to the left of the photo and harbor docks are in the center at the water's edge. Buildings in the nearground are remnants of the former Adak Naval Air Station. Adak provides a fueling port and crew transfer facility for fishing ships based in Seattle and Alaska. The island has housing, a restaurant, grocery store, ship supply store, and a large fish processing facility. Photo by Amy Macpherson. 


\section{REGIONAL TSUNAMI HAZARD ASSESSMENT FOR ANDREANOF ISLANDS, ALASKA}

E.N. Suleimani, D.J. Nicolsky, R.D. Koehler, and J.B. Salisbury

Report of Investigations 2017-2

State of Alaska

Department of Natural Resources

Division of Geological \& Geophysical Surveys 
STATE OF ALASKA

Mike Dunleavy, Governor

\section{DEPARTMENT OF NATURAL RESOURCES}

Corri Feige, Commissioner

\section{DIVISION OF GEOLOGICAL \& GEOPHYSICAL SURVEYS}

Steve Masterman, State Geologist and Director

Publications produced by the Division of Geological \& Geophysical Surveys (DGGS) are available for free download from the DGGS website (dggs.alaska.gov). Publications on hard-copy or digital media can be examined or purchased in the Fairbanks office:

Alaska Division of Geological \& Geophysical Surveys 3354 College Rd., Fairbanks, Alaska 99709-3707

Phone: (907) 451-5010 Fax (907) 451-5050

dggspubs@alaska.gov|dggs.alaska.gov

DGGS publications are also available at:

Alaska State Library, Historical Collections \& Talking Book Center 395 Whittier Street Juneau, Alaska 99811

Alaska Resource Library and Information Services (ARLIS) 3150 C Street, Suite 100

Anchorage, Alaska 99503

Suggested citation:

Suleimani, E.N., Nicolsky, D.J., and Koehler, R.D., 2017, Regional tsunami hazard assessment for Andreanof Islands, Alaska: Alaska Division of Geological \& Geophysical Surveys Report of Investigation 2017-2, 19 p. http://doi.org/10.14509/29704
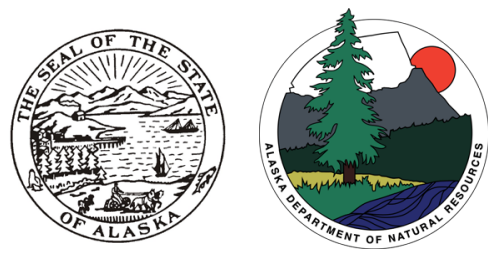


\section{Contents}

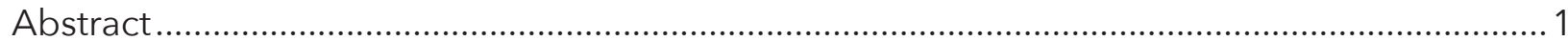

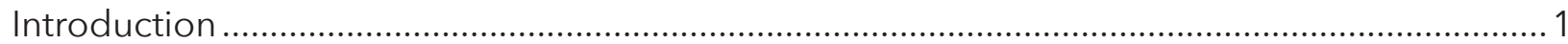

Project Background: Regional and Historical Context............................................................ 2

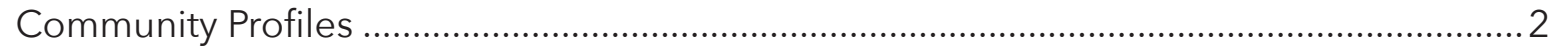

Seismic and Tsunami History ............................................................................................

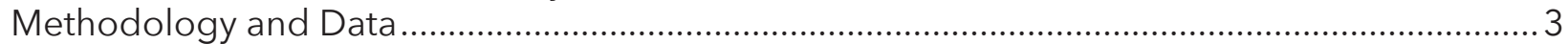

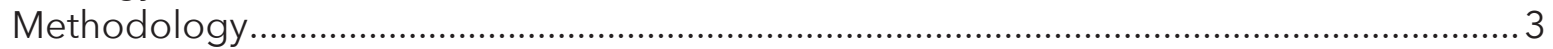

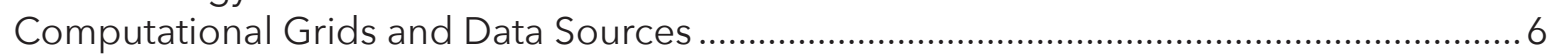

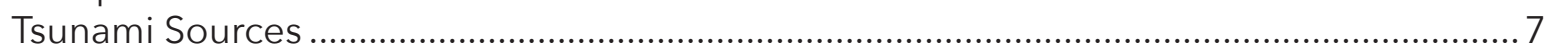

Numerical Model of Tsunami

Propagation and Runup .......................................................................................11

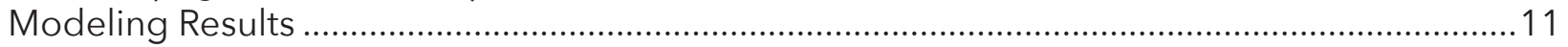

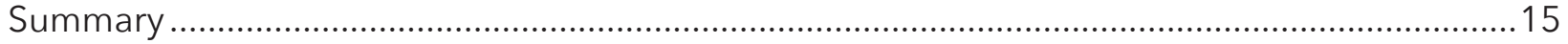

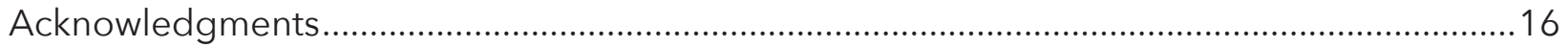

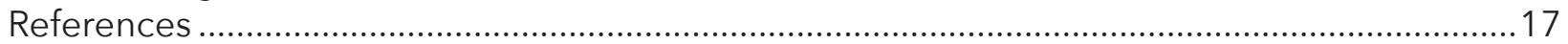

Figures

Figure 1. Map of the central Aleutian Islands and the Andreanof Islands group ........................2

Figure 2. Nesting of the bathymetry/topography grids for numerical modeling

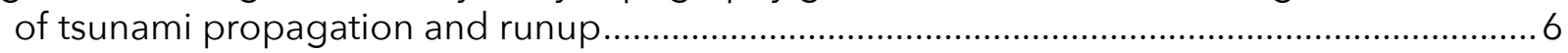

Figure 3. Proposed slip distributions along the plate interface for scenarios 1-3......................9

Figure 4. Vertical coseismic deformations corresponding to scenarios 1-3 .............................10

Figure 5. Maximum tsunami wave height for scenarios 1-3 in the level 3 grid for Adak ..........12

Figure 6. Maximum tsunami wave height for scenarios 1-3 in the level 3 grid for Atka............13

Figure 7. Maximum composite tsunami wave height at Adak ....................................................14

Figure 8. Maximum composite tsunami wave height at Atka .......................................................14

Figure 9. Time series of water level for scenarios 1-3 .............................................................15

\section{Tables}

Table 1. Tsunami effects at Adak and Atka................................................................................... 4

Table 2. Nested grids used to compute propagation of tsunami waves generated in the Pacific Ocean to the communities of Adak and Atka ............................................................ 5

Table 3. Significant credible tsunami sources for Adak and Atka................................................. 8

\section{Map Sheets}

Sheet 1. Tsunami hazard map of Adak, Alaska

Sheet 2. Tsunami hazard map of Atka, Alaska 



\title{
REGIONAL TSUNAMI HAZARD ASSESSMENT FOR ANDREANOF ISLANDS, ALASKA
}

\author{
E.N. Suleimani, ${ }^{1}$ D.J. Nicolsky, ${ }^{1}$ R.D. Koehler, ${ }^{2}$ and J.B. Salisbury ${ }^{2}$
}

\begin{abstract}
We assess potential tsunami hazard for the central Aleutian communities of Adak and Atka, on the Andreanof Islands, Alaska. The primary tsunami hazard for these communities is considered to be near-field, with the major threat originating from tsunamigenic earthquakes along the Alaska-Aleutian megathrust. We numerically model tsunamis generated by three different megathrust earthquakes, analyze tsunami wave dynamics, and develop tsunami hazard maps for the coastal communities of Adak and Atka. The hypothetical tsunami scenarios that we examined simulate $M_{w} 9.0$ megathrust earthquakes with a slip distribution in the 5-35 $\mathrm{km}$ (3-22 $\mathrm{mi}$ ) depth range along the Alaska-Aleutian megathrust. The maximum runup heights are $23.4 \mathrm{~m}$ (76.8 ft) in Adak and $31.1 \mathrm{~m}$ (102 ft) in Atka. Results presented here are intended to provide guidance to local emergency management agencies in initial tsunami inundation assessment, evacuation planning, and public education for mitigation of future tsunami hazards.
\end{abstract}

\section{INTRODUCTION}

Subduction of the Pacific plate under the North American plate has resulted in numerous great earthquakes and has the highest potential to generate tsunamis in Alaska (Dunbar and Weaver, 2008). The Alaska-Aleutian megathrust (fig. 1), the fault formed by the Pacific-North American plate interface, produces the majority of large earthquakes in the U.S. (ComCat, the ANSS Comprehensive Earthquake Catalog, https://earthquake.usgs.gov/ data/comcat/). The latest sequence of great earthquakes along the Alaska-Aleutian megathrust began in 1938 with a M 8.3 earthquake west of Kodiak Island (Estabrook and others, 1994). Four subsequent events, the $1946 \mathrm{M}_{\mathrm{w}} 8.6$ Aleutian (Lopez and Okal, 2006), the $1957 \mathrm{M}_{\mathrm{w}} 8.6$ Andreanof Islands (Johnson and Satake, 1993), the $1964 \mathrm{M}_{\mathrm{w}} 9.2$ Alaska (Kanamori, 1970), and the $1965 \mathrm{M}_{\mathrm{w}} 8.7$ Rat Island (Wu and Kanamori, 1973) earthquakes, ruptured almost the entire length of the megathrust. Tsunamis generated by these great earthquakes reached Alaska coastal communities within minutes and resulted in widespread damage and loss of life (National Centers for Environmental Information/ World Data Service [NCEI/WDS]). Saving lives and property in the future depends on community preparedness, which further depends on estimating potential flooding of the coastal zone in the event of a local or distant tsunami.

The future occurrence of earthquakes and tsunamis necessitates the development of inundation and tsunami evacuation maps for use in tsunami hazard mitigation. In this report, we provide an analysis of numerical modeling of tsunamis and develop tsunami hazard maps ${ }^{3}$ for the communities of Adak and Atka, the two largest communities on the Andreanof Islands. This report is intended for use by scientists, engineers, and planners interested

${ }^{1}$ Geosphysical Institute, University of Alaska, P.O. Box 757320, Fairbanks, Alaska 99775-7320, ensuleimani@alaska.edu ${ }^{2}$ Alaska Division of Geological \& Geophysical Surveys, 3354 College Rd., Fairbanks, Alaska 99709-3707; R.D. Koehler now with Nevada Bureau of Mines and Geology, University of Nevada, Reno, 1664 North Virginia Street, MS 178, Reno, NV 89557, rkoehler@unr.edu

${ }^{3}$ This report is different than previous reports (such as Nicolsky and others, 2013, 2014; Suleimani and others, 2013, $2014,2015)$, in which the authors completed a thorough sensitivity study and considered numerous tsunami sources. In this assessment we base an estimation of the potential inundation zone only on three significant tsunami scenarios. Although the modeled tsunami inundation cannot be considered exhaustive, it is still thought to provide a sound approximation of the potential tsunami inundation zone in the communities. 
in applying modeling results to develop tsunami inundation and evacuation maps. Digital data and documentation provided with the report enable technical users to explore the range of potential tsunami hazards expected in future events.

\section{PROJECT BACKGROUND: REGIONAL AND HISTORICAL CONTEXT}

\section{Community Profiles}

The community of Adak (51.53'0"N, $\left.176.38^{\prime} 42^{\prime} \mathrm{W}\right)$, population 247 , is located on Adak Island, in the Andreanof Islands (fig. 1). It is $1,930 \mathrm{~km}(1,200 \mathrm{mi})$ southwest of Anchorage and $724 \mathrm{~km}$ (450 mi) west of Dutch Harbor. According to the Alaska Department of Commerce, Community, and Economic Development, Division of Community and Regional Affairs (DCCED/DCRA, 2013), Adak Island, once heav- ily populated, was abandoned in the early 1800 s as the Aleutian Islands hunters followed the Russian fur trade eastward. During World War II, Adak's military installations allowed U.S. forces to mount successful military operations. After the war, Adak was developed as a Naval Air Station, which closed on March 31, 1997. In 2001, a community formed as a second-class city. Adak currently provides a fueling port and crew transfer facility for fishing ships based in Seattle and Alaska. The community has an airport, docks, housing facilities, a restaurant, grocery store, and ship supply store. Adak Fisheries, LLC, an employer of a large seasonal staff, processes Pacific cod, pollock, mackerel, halibut, and snow and king crab.

The small community of Atka $\left(52^{\circ} 11^{\prime} 57^{\prime \prime} \mathrm{N}\right.$, $\left.174^{\circ} 12^{\prime} 48^{\prime \prime} \mathrm{W}\right)$, population 70 , is on the east side of Atka Island in the Andreanof Islands (fig. 1). It is $1,770 \mathrm{~km}(1,100 \mathrm{mi})$ southwest of Anchor-

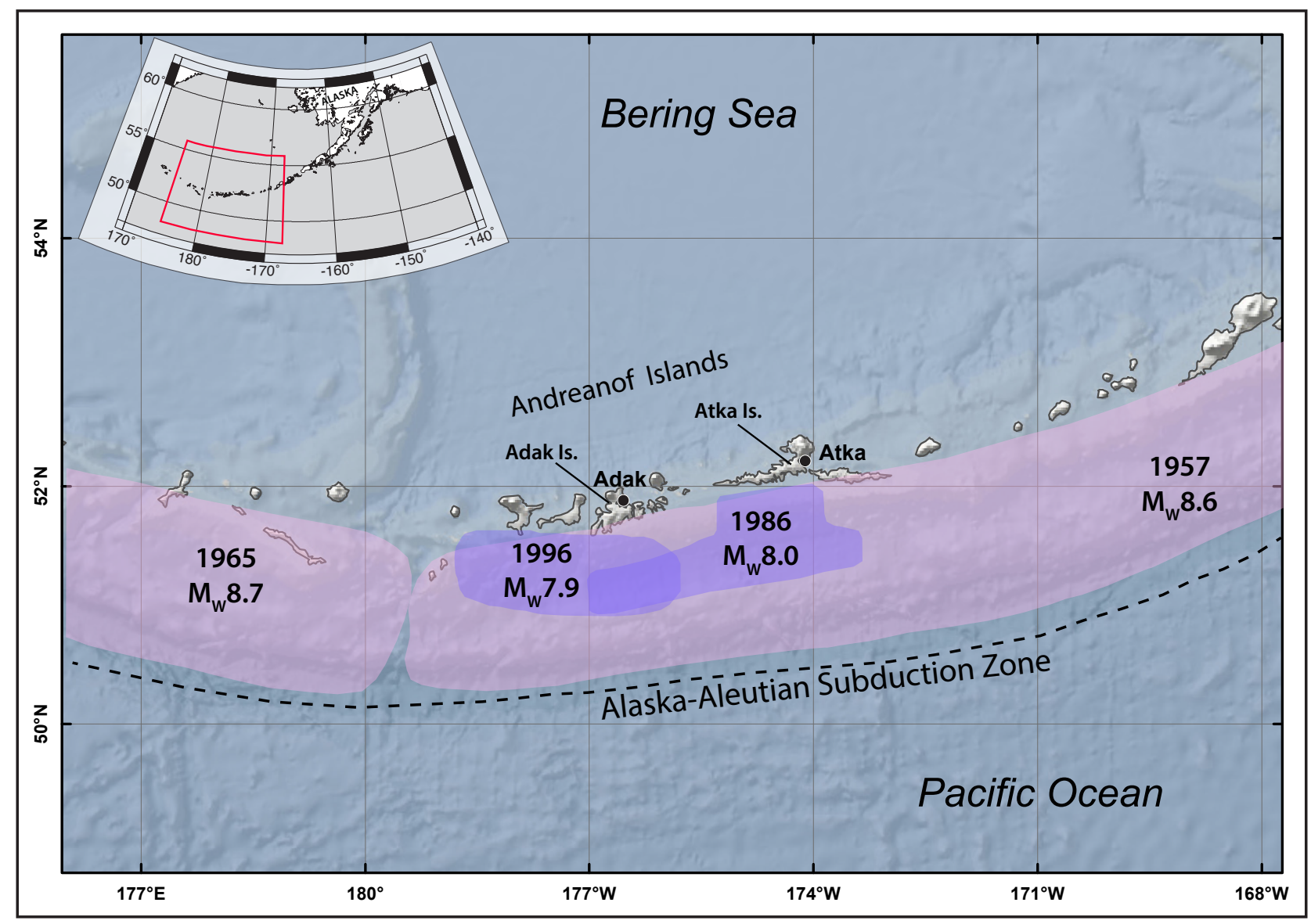

Figure 1. Map of the central Aleutian Islands and the Andreanof Islands group. Rupture areas of the latest sequence of great and large earthquakes are shown by shaded polygons. 
age, $563 \mathrm{~km}$ (350 mi) west of Dutch Harbor, and $172 \mathrm{~km}(107 \mathrm{mi})$ east of Adak. Atka is a traditional Unangan (Aleut) community and a federally recognized tribe. According to DCCED/ DCRA (2013), the island has been occupied by Unangans for at least 2,000 years. The first contact with Russians occurred in 1747, and Atka became an important trade site and safe harbor. During World War II, Atka was burned to the ground but was rebuilt by the U.S. Navy after the war, at which time residents were allowed to return. The city was incorporated in 1988. The community has an airport, docks, and housing facilities. Scheduled air services are available three times weekly from Unalaska, and planes can also be chartered to the community from Cold Bay or Unalaska.

\section{Seismic and Tsunami History}

The rate of plate convergence near the Andreanof Islands is approximately $73 \mathrm{~mm}$ (2.9 in) per year (Cross and Freymueller, 2007) and the subduction zone has ruptured in three major earthquakes in the last 60 years (fig. 1). The 1957 ( $\left.\mathrm{M}_{\mathrm{w}} 8.6\right)$ earthquake ruptured from near the Andreanof Islands east to the Unalaska region (Johnson and others, 1994). The 1986 Andreanof Islands earthquake $\left(M_{w} 8.0\right)$ and the 1996 event $\left(M_{w} 7.9\right)$ ruptured within the western third of the 1957 rupture area. The 1996 rupture area included the region west of the Andreanof Islands and overlapped the western part of the 1986 rupture area (Tanioka and Gonzalez, 1998; fig. 1). Cross and Freymueller (2007) used GPS measurements to study plate coupling in the Andreanof region of the subduction zone and found strong along-strike variations in plate coupling. They showed that the combined rupture area of the 1986 and 1996 earthquakes was a region of high slip deficit. This combined rupture area represents the western third of the 1957 rupture zone, which had high slip during the earthquake (Johnson and others, 1994). Cross and Freymueller (2007) found that the plate interface is nearly 100 percent locked west of the 1986 and 1996 earthquakes at depths from 15-45 km (9-28 $\mathrm{mi}$ ), and that east of the earthquakes the subduction zone is largely creeping.
According to the National Geophysical Data Center Global Historical Tsunami Database (http://doi.org/10.7289/V5PN93H7), about 50 tsunamis have affected Adak in recorded history, with maximum wave heights ranging from $1 \mathrm{~cm}$ $(0.4 \mathrm{in})$ to $2.7 \mathrm{~m}(8.9 \mathrm{ft})$. The same database lists ten tsunamis that reached Atka, with maximum wave heights ranging from $6 \mathrm{~cm}$ (2.4 in) to 9.14 $\mathrm{m}(30 \mathrm{ft})$. Table 1 summarizes tsunami events that produced wave heights greater than $15 \mathrm{~cm}(0.5 \mathrm{ft})$ at Adak and Atka.

\section{METHODOLOGY AND DATA Methodology}

The regional tsunami hazard maps for Adak and Atka described in this report represent the results of the ongoing combined effort of State and Federal agencies to assist coastal communities in Alaska with tsunami hazard assessment. During recent years, tsunami inundation maps and reports have been published for a number of communities (Nicolsky and others, 2011a, 2013, 2014; Suleimani and others, 2010, 2013, 2015). In these studies, the authors performed numerical modeling of tsunami waves for each community using high-resolution digital elevation models (DEMs) of combined bathymetry and topography which have been verified with local real-time kinetic (RTK) global position system (GPS) surveys. The potential inundation resulting from various hypothetical tsunamis was simulated with the best available high-resolution data, with a typical spatial resolution of $15 \mathrm{~m}$ ( $49 \mathrm{ft})$. The authors of those reports also performed sensitivity studies to determine a possible slip distribution for the worst-case credible tsunami events. In addition, multiple constraints such as regional seismicity, tectonic processes, and geodetic and paleotsunami data were taken into account.

In this report we use a different approach because the currently available DEMs of Adak and Atka can have large horizontal and vertical discrepancies, and hence any tsunami inundation modeling might have large errors and thus may misinform emergency managers about the true location of the potential inundation zone. Nevertheless, 
Table 1. Tsunami effects at Adak and Atka. Data from the National Centers for Environmental Information Global Historical Tsunami Database (http://doi.org/10.7289/V5PN93H7) and comments from Lander (1996).

\begin{tabular}{|c|c|c|c|c|}
\hline Date & $\begin{array}{l}\text { Magnitude } \\
\left(\mathrm{M}_{\mathbf{w}}\right)\end{array}$ & Origin & $\begin{array}{l}\text { Maximum } \\
\text { Water } \\
\text { Height }(\mathrm{m})\end{array}$ & Comments \\
\hline \multicolumn{5}{|l|}{ Adak } \\
\hline 04/01/1946 & 8.6 & Unimak Island, Alaska & 0.23 & \\
\hline $11 / 04 / 1952$ & 9.0 & Kamchatka Peninsula & 1.1 & The waves slightly overflowed the banks of the harbor. \\
\hline 03/09/1957 & 8.6 & Aleutian Islands & 2.7 & $\begin{array}{l}\text { Tsunami caused severe damage. All structures } \\
\text { at the fuel and oil dock washed away up to } 4 \mathrm{~m} \\
\text { elevation; oil pipelines damaged. }\end{array}$ \\
\hline $5 / 22 / 1960$ & 9.5 & Chile & 1.1 & \\
\hline $03 / 28 / 1964$ & 9.2 & Gulf of Alaska & 0.27 & \\
\hline 02/04/1965 & 8.7 & Rat Island & 0.46 & Sea level fell 1.2 feet in 15 minutes. \\
\hline $11 / 22 / 1969$ & 7.7 & Kamchatka Peninsula & 0.3 & \\
\hline 05/07/1986 & 8.0 & Andreanof Islands & 0.88 & \\
\hline 06/10/1996 & 7.9 & Andreanof Islands & 0.51 & \\
\hline $11 / 15 / 2006$ & 8.3 & Kuril Islands & 0.2 & \\
\hline $02 / 27 / 2010$ & 8.8 & Chile & 0.38 & \\
\hline 03/11/2011 & 9.0 & Honshu, Japan & 1.1 & \\
\hline \multicolumn{5}{|l|}{ Atka } \\
\hline 03/09/1957 & 8.6 & Alaska & 9.14 & $\begin{array}{l}\text { Tsunami washed the skiffs up the creek and } \\
\text { washed away all of the boathouses and also the } \\
\text { oil supply of the village. Big pilings were washed } \\
\text { to a height of about } 10 \mathrm{~m} \text {. }\end{array}$ \\
\hline $02 / 27 / 2010$ & 8.8 & Chile & 0.42 & \\
\hline
\end{tabular}

development of an approximate tsunami inundation zone is an important task that could help to mitigate tsunami hazard in both communities. For Adak and Atka, we therefore follow the National Tsunami Hazard Mitigation Program (NTHMP) guidelines ${ }^{4}$ for determining tsunami hazard zones in areas that have either low risk due to small population size and minimal infrastructure vulnerability, or are not scheduled to receive high-resolution tsunami inundation maps in the near future and wish to initiate planning and preparation efforts. For the communities of Adak and Atka, we simulate a limited number of significant potential tsunamis and develop tsunami hazard maps, which are needed to support informed decision making in the event of a tsunami, and can also help with advance development of tsunami evacuation strategies. Producing a tsunami hazard map consists of several steps, which are listed below and described in detail later in the report.

1. Develop computational grids. To propagate a tsunami wave from its source area to coastal locations, we use numerical grids (listed in table 2) of increasing resolution that are based on tsunami DEMs developed by the National Centers for Environmental Information (NCEI) of the National Oceanic and Atmospheric Administration (NOAA).

2. Identify potential tsunami sources. We identify and characterize potential tsunami sources using information on region-specific

${ }^{4}$ http://nws.weather.gov/nthmp/documents/Inundationareaguidelinesforlowhazardareas.pdf 
Table 2. Nested grids used to compute propagation of tsunami waves generated in the Pacific Ocean to the communities of Adak and Atka. The fine-resolution grids are used to compute the inundation. Note that the grid resolution in meters is not uniform and is used to illustrate grid fineness in the Andreanof Islands region. The first dimension is the longitudinal grid resolution; the second is the latitudinal resolution.

\begin{tabular}{|c|c|c|c|c|}
\hline \multirow[b]{2}{*}{ Grid Name } & \multicolumn{2}{|c|}{ Resolution } & \multirow[b]{2}{*}{ West-East Boundaries } & \multirow[b]{2}{*}{ South-North Boundaries } \\
\hline & $\begin{array}{c}\text { Arc- } \\
\text { seconds }\end{array}$ & $\begin{array}{c}\text { Meters } \\
\text { (near } \\
\text { Adak) }\end{array}$ & & \\
\hline Level 0, Northern Pacific & $120 \times 120$ & $\approx 1,850 \times 3,700$ & $120^{\circ} 00^{\prime} E-100^{\circ} 00^{\prime} W$ & $10^{\circ} 00^{\prime} N-65^{\circ} 66^{\prime} N$ \\
\hline Level 1, Western Aleutians & $24 \times 24$ & $\approx 430 \times 740$ & $171^{\circ} 57^{\prime} 28^{\prime \prime} E-172^{\circ} 10^{\prime} 40^{\prime \prime} \mathrm{W}$ & $48^{\circ} 43^{\prime} 12^{\prime \prime} \mathrm{N}-55^{\circ} 30^{\prime} 58^{\prime \prime} \mathrm{N}$ \\
\hline $\begin{array}{l}\text { Level 2, Coarse-resolution } \\
\text { Andreanof Islands }\end{array}$ & $8 \times 8$ & $\approx 150 \times 250$ & $179^{\circ} 34^{\prime} 57^{\prime \prime} E-172^{\circ} 39^{\prime} 40^{\prime \prime} \mathrm{W}$ & $51^{\circ} 08^{\prime} 17^{\prime \prime} \mathrm{N}-52^{\circ} 48^{\prime} 58^{\prime \prime} \mathrm{N}$ \\
\hline $\begin{array}{l}\text { Level 3, Fine-resolution, } \\
\text { Adak }\end{array}$ & $8 / 3 \times 8 / 3$ & $\approx 48 \times 82$ & $178^{\circ} 18^{\prime} 29^{\prime \prime} W-175^{\circ} 34^{\prime} 21^{\prime \prime} \mathrm{W}$ & $51^{\circ} 32^{\prime} 34^{\prime \prime} \mathrm{N}-52^{\circ} 12^{\prime} 27^{\prime \prime} \mathrm{N}$ \\
\hline Level 3, Fine-resolution, Atka & $8 / 3 \times 8 / 3$ & $\approx 48 \times 83$ & $175^{\circ} 24^{\prime} 28^{\prime \prime} \mathrm{W}-172^{\circ} 49^{\prime} 33^{\prime \prime} \mathrm{W}$ & $51^{\circ} 46^{\prime} 29^{\prime \prime} \mathrm{N}-52^{\circ} 30^{\prime} 10^{\prime \prime} \mathrm{N}$ \\
\hline
\end{tabular}

subduction processes, geophysical data, and research models. We also use ranges of maximum considered tsunami events from previously published tsunami inundation reports (Nicolsky and others, 2011a, 2013, 2014; and Suleimani and others, 2010, 2013, 2015).

3. Numerically model tsunami wave propagation. We perform numerical calculations for all considered potential tsunami sources. For each scenario, we model the water dynamics in each computational grid and process numerical results from the Level 3 grids that include coastal communities of interest.

4. Calculate maximum composite wave heights. For each tsunami scenario, we first calculate the maximum tsunami wave heights in the highest-resolution grid over the course of the entire model run in the following way: at each grid point, tsunami wave height is computed at every time step during the tsunami propagation time, and the maximum value is retained. Then we compute the composite maximum wave height from all considered scenarios by again choosing the maximum value for each grid point among all scenarios, and plot the results in the vicinity of the coastal community and surrounding waters.

5. Extrapolate the near-shore maximum composite wave height on land. Following the above-referenced NTHMP guidelines, we extrapolate the modeling data on land to estimate the inundation zone. Specifically, we first calculate the maximum value of the tsunami height at the community and multiply this value by a safety factor. Please note that according to Synolakis and others (2007), the benchmarking of a tsunami model with the field data requires that numerical predictions for the maximum runup should not differ by more than 20 percent from the measurements. Therefore, in order to incorporate an uncertainty due to a numerical model, the safety factor needs to be at least 1.2. Similarly, in the Federal Emergency Management Agency guidelines (Applied Technology Council, 2012; Technical Report FEMA P-646), it is recommended that "the design runup elevation be taken as 1.3 times the predicted maximum runup elevation to envelop the potential variability in the estimates of modeling." In this report, we employ the same safety factor, 1.3 , as in the FEMA guidelines, and then select an elevation contour corresponding to the scaled 
tsunami height on a community map. The contour defines a boundary of the tsunami hazard zone and is to be used by emergency planners as a guideline for various tsunami mitigation activities.

\section{Computational Grids and Data Sources}

To develop a regional tsunami hazard map we use a series of nested computational grids. A nested grid allows for higher resolution in areas where it is needed without expending computer resources in areas where it is not. The bathymetric and topographic relief in each nested grid is based on digital elevation models (DEMs) developed at the National Centers for Environmental Information (NCEI) of the National Oceanic \& Atmo- spheric Administration (NOAA) in Boulder, Colorado. The extent of each grid used for the Adak and Atka mapping project is shown in figure 2 and listed in table 2 . The coarsest grid, with 2-arc-minute (approximately $2 \mathrm{~km}$ ) resolution, spans the central and northern Pacific Ocean. The bathymetric data for the 2-arc-minute-resolution grid is extracted from the ETOPO2 dataset (NCEI). We use two intermediate grids between the coarsest- and highest-resolution grids (table 2). The first intermediate grid of 24 arc-second resolution (Level 1) covers western Aleutian Islands. It was developed to accommodate the current tsunami mapping project for the Andreanof Islands as well as future mapping efforts for communities located on the Near Islands. The data sources and methodology used to develop 24-, 8-, and 8/3-arc-second

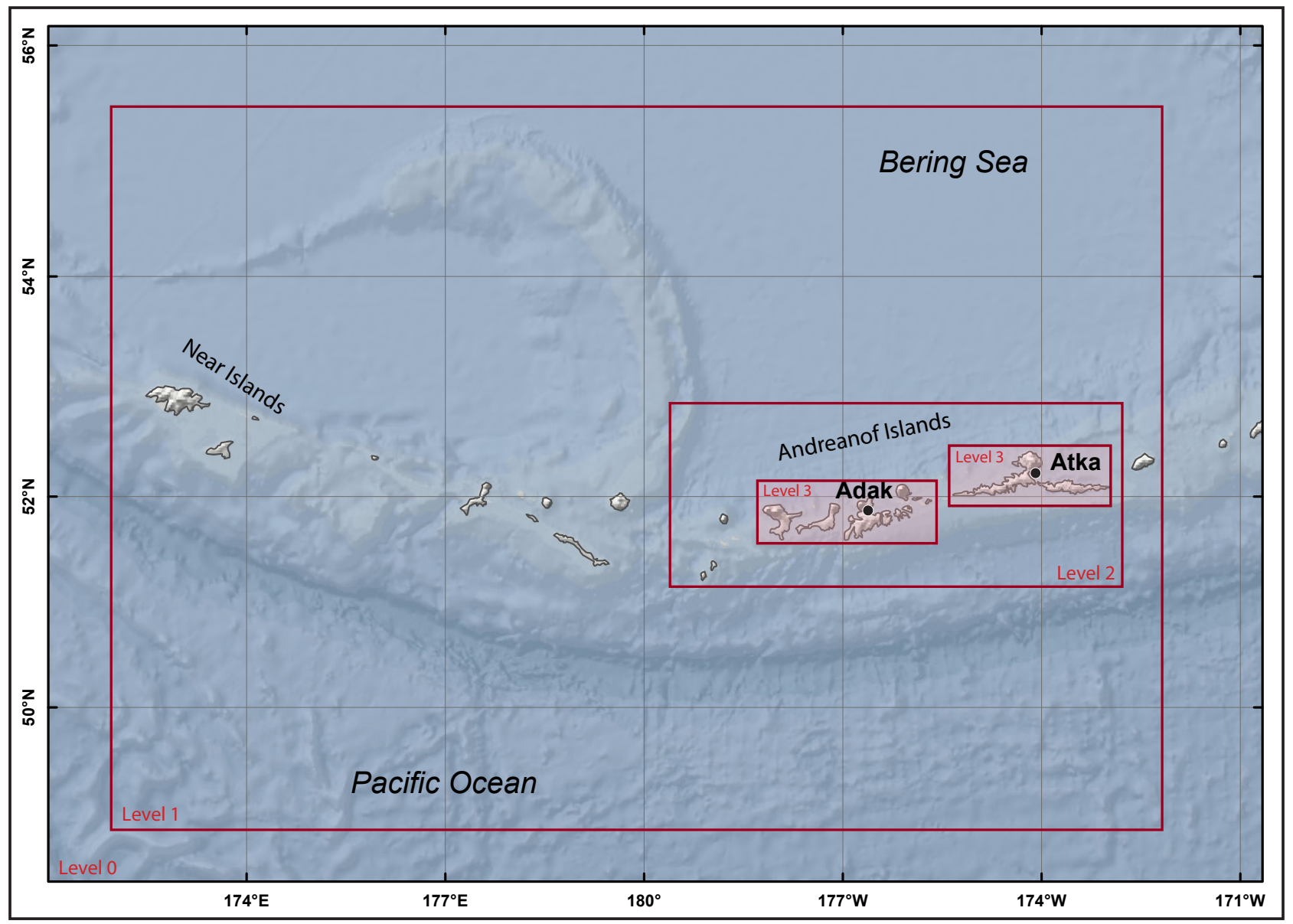

Figure 2. Nesting of the bathymetry/topography grids for numerical modeling of tsunami propagation and runup. The coarsest grid, Level 0, covers the central and northern Pacific Ocean. The location of each embedded grid is marked by a red rectangle. Refer to table 2 for grid parameters. 
DEMs are described in detail by Lim and others (2011), Carignan and others (2009), and Friday and others (2011).

The fine-resolution grid for Adak covers the western Andreanof Islands including Adak Island. The fine-resolution grid for Atka covers the eastern Andreanof Islands including Atka Island. The spatial resolution of the fine-resolution grid cells, with about $48 \times 82 \mathrm{~m}(157 \times 269 \mathrm{ft})$ dimensions, satisfies NOAA minimum recommended requirements for estimation of the tsunami hazard zone (National Tsunami Hazard Mapping Program [NTHMP], 2010); however, no DEM verification efforts were conducted to reduce uncertainties in the fine-resolution (level 3) Atka and Adak grids. Therefore, in this report we do not perform high-resolution runup modeling, but provide an estimation of the tsunami hazard zone by extrapolating the maximum composite tsunami wave height on land according to the tsunami scenarios described below. We account for uncertainties inherent to this method by applying the safety factor to the estimated hazard zone.

\section{Tsunami Sources}

In this project we employ a deterministic method to develop potential tsunami sources, which is distinctly different from the probabilistic tsunami hazard analysis used in projects with different objectives, such as land-use planning or insurance estimates (Geist and Parsons, 2006). Alaska tsunami hazard maps are produced on the basis of significant credible tsunami scenarios for a given segment of the coastline. Although we do not develop worst-case credible tsunami scenarios in this report as we have in some previous reports, we use the same underlying assumptions and results regarding the maximum considered scenarios for other locations along the Alaska-Aleutian subduction zone.

In this regional tsunami hazard assessment project we consider three characteristic tsunami scenarios that produced simulated devastating waves at other Alaska coastal communities (Nicolsky and others, 2015; Suleimani and others,
2016). These potential ruptures, with a uniform slip distribution along the strike, are positioned on the Alaska-Aleutian subduction interface south of the communities of Adak and Atka. The three sources differ in the downdip slip distribution pattern such that the depth range at which the maximum slip occurs varies from the shallow region, close to the trench, to the deeper parts of the plate interface. All ruptures have the same extent, which is determined by the location of communities and constrained by the seismic moment. We construct the scenarios using the following procedure:

1. We place hypothetical ruptures on the megathrust and determine their lengths. In this report, the hypothetical ruptures extend from about $179^{\circ} 30^{\prime} \mathrm{W}$ to $171^{\circ} \mathrm{W}$ in the along-strike direction. Both Adak and Atka are located within this rupture length.

2. To simulate potential tsunami sources on the Alaska-Aleutian megathrust, we employ a discretized model (Nicolsky and others, 2015) of the Alaska-Aleutian plate interface (Hayes and others, 2012) between the subducting and overriding plates. To define coseismic slip of hypothetical ruptures in the downdip direction, we use either a previously considered slip distribution or parameterize it by formulas according to Freund and Barnett (1976).

3. We allow a maximum slip of $46 \mathrm{~m}$ (151 $\mathrm{ft}$ ) in the shallow part of the rupture, and a maximum slip of $35 \mathrm{~m}(115 \mathrm{ft})$ in deeper areas. The assumed maximum slip of 35-37 $\mathrm{m}(115-121 \mathrm{ft})$ in deeper parts of the rupture is consistent with other modeling studies (such as Butler, 2014) for this region.

Below we describe the significant credible tsunami sources for Adak and Atka. The proposed slip distributions for these scenarios are shown in figure 3; vertical coseismic deformations are shown in figure 4 . The main rupture parameters and amount of permanent subsidence in the communities are listed in Table 3 . 
Table 3. Significant credible tsunami sources for Adak and Atka.

\begin{tabular}{|c|c|c|c|c|c|c|c|c|}
\hline & Scenarios & $\begin{array}{l}\text { Depth } \\
\text { range, } \\
\text { km (mi) }\end{array}$ & $\begin{array}{l}\text { Maximum } \\
\text { slip depth } \\
\text { range, } \\
\text { km (mi) }\end{array}$ & $\begin{array}{l}\text { Maximum } \\
\text { slip, m (ft) }\end{array}$ & $\begin{array}{l}\text { Maximum } \\
\text { regional } \\
\text { subsidence, } \\
\text { m (ft) }\end{array}$ & $\begin{array}{l}\text { Maximum } \\
\text { regional } \\
\text { uplift, } m(f t)\end{array}$ & $\begin{array}{c}\text { Actual } \\
\text { subsidence } \\
\text { in Adak, } \\
\text { m (ft) }\end{array}$ & $\begin{array}{c}\text { Actual } \\
\text { subsidence } \\
\text { in Atka, } \\
\text { m (ft) }\end{array}$ \\
\hline 1 & $\begin{array}{l}\text { Mw } 9.0 \text { earthquake: } \\
\text { SAFRR-type event, } \\
\text { slip near the trench }\end{array}$ & $8-54(5-33)$ & $\begin{array}{c}11-14(7- \\
8.5)\end{array}$ & $\begin{array}{c}55-65(180- \\
213)\end{array}$ & $-2.7(-8.8)$ & $13.8(45.3)$ & $-0.9(-2.9)$ & $-0.6(-1.9)$ \\
\hline 2 & $\begin{array}{l}\text { Mw } 9.0 \text { earthquake: } \\
\text { Maximum slip at } \\
15-25 \mathrm{~km}(9.3-15.5 \\
\text { mi) depth }\end{array}$ & $\begin{array}{c}5-35(3- \\
21.7)\end{array}$ & $\begin{array}{c}15-25(9.3- \\
15.5)\end{array}$ & $\begin{array}{c}34-35(111- \\
115)\end{array}$ & $-6.4(-21.0)$ & $13.6(44.6)$ & $-1.4(-4.6)$ & $-1.0(-3.3)$ \\
\hline 3 & $\begin{array}{l}\text { Mw } 9.0 \text { earthquake: } \\
\text { Maximum slip at } \\
\text { 25-35 km (15.5-21.7 } \\
\text { mi) depth }\end{array}$ & $14-45(8-26)$ & $\begin{array}{c}25-35(15.5- \\
21.7)\end{array}$ & $\begin{array}{c}34-35(111- \\
115)\end{array}$ & $-5.6(-18.3)$ & $17.6(57.7)$ & $-2.9(-9.5)$ & $-2.3(-7.5)$ \\
\hline
\end{tabular}

Scenario 1. $M_{w} 9.0$ earthquake: SAFRR-type event

Scenario 2. $M_{w} 9.0$ earthquake: Maximum slip at 15-25 km (9.3-15.5 mi) depth

Scenario 3. $M_{w} 9.0$ earthquake: Maximum slip at 25-35 km (15.5$21.7 \mathrm{mi}$ ) depth
This event is a hypothetical Tohoku-type $\mathrm{M}_{\mathrm{w}} 9.0$ earthquake rupturing the Alaska-Aleutian megathrust. During the 2011 Tohoku earthquake a large amount of slip occurred between the subducting and overriding plates near the Japan trench (Fujii and others, 2011; Shao and others, 2011). The USGS Science Application for Risk Reduction (SAFRR) project, in collaboration with NOAA and State of California agencies, developed a plausible hypothetical tsunami scenario (Kirby and others, 2013) to describe the impacts of a tsunami generated by an earthquake in the Alaska Peninsula region (Ross and others, 2013). For Scenario 1 in this report we assume that the slip distribution in the downdip direction is the same as that in the SAFRR source, where greater slip occurs closer to the trench. This hypothetical rupture is positioned across the shelf area from the communities of Adak and Atka. The slip is distributed almost uniformly along the strike except for the edges of the rupture where it tapers. The maximum slip of $46 \mathrm{~m}(151 \mathrm{ft})$ is at a depth of $5-15 \mathrm{~km}$ (3.1-9.3 mi). The proposed slip distribution is shown in figure 3A; vertical coseismic deformations for this scenario are shown in figure $4 \mathrm{~A}$.

This event is a hypothetical $\mathrm{M}_{\mathrm{w}} 9.0$ earthquake rupturing the AlaskaAleutian megathrust. The slip is distributed almost uniformly along strike except for the edges of the rupture where it tapers. The maximum slip of $35 \mathrm{~m}(114.8 \mathrm{ft})$ is at a depth of $15-25 \mathrm{~km}(9.3-15.5 \mathrm{mi})$. The proposed slip distribution is shown in figure $3 \mathrm{~B}$; vertical coseismic deformations for this scenario are shown in figure $4 \mathrm{~B}$.

This event is a hypothetical $M_{w} 9.0$ earthquake rupturing the AlaskaAleutian megathrust. The slip is distributed almost uniformly along strike except for the edges of the rupture where it tapers. The maximum slip of $35 \mathrm{~m}(114.8 \mathrm{ft})$ is at a depth of $25-35 \mathrm{~km}(15.5-21.7 \mathrm{mi})$. The proposed slip distribution is shown in figure $3 \mathrm{C}$; vertical coseismic deformations for this scenario are shown in figure $4 \mathrm{C}$. 

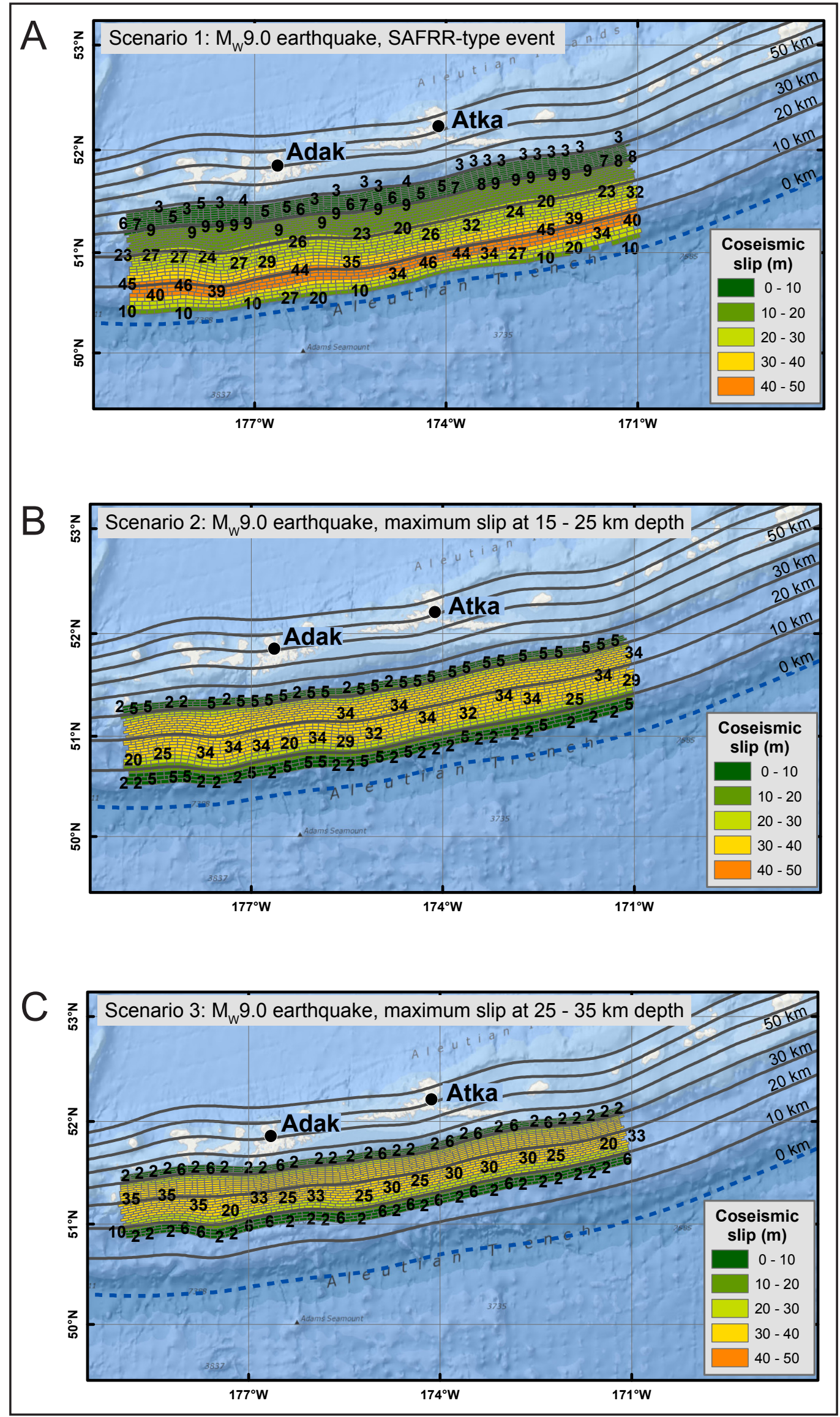

Figure 3. Proposed slip distributions along the plate interface for scenarios 1-3. Slip values in meters are marked by small black labels. The depth contours of the AlaskaAleutian subduction interface are shown by gray lines. 


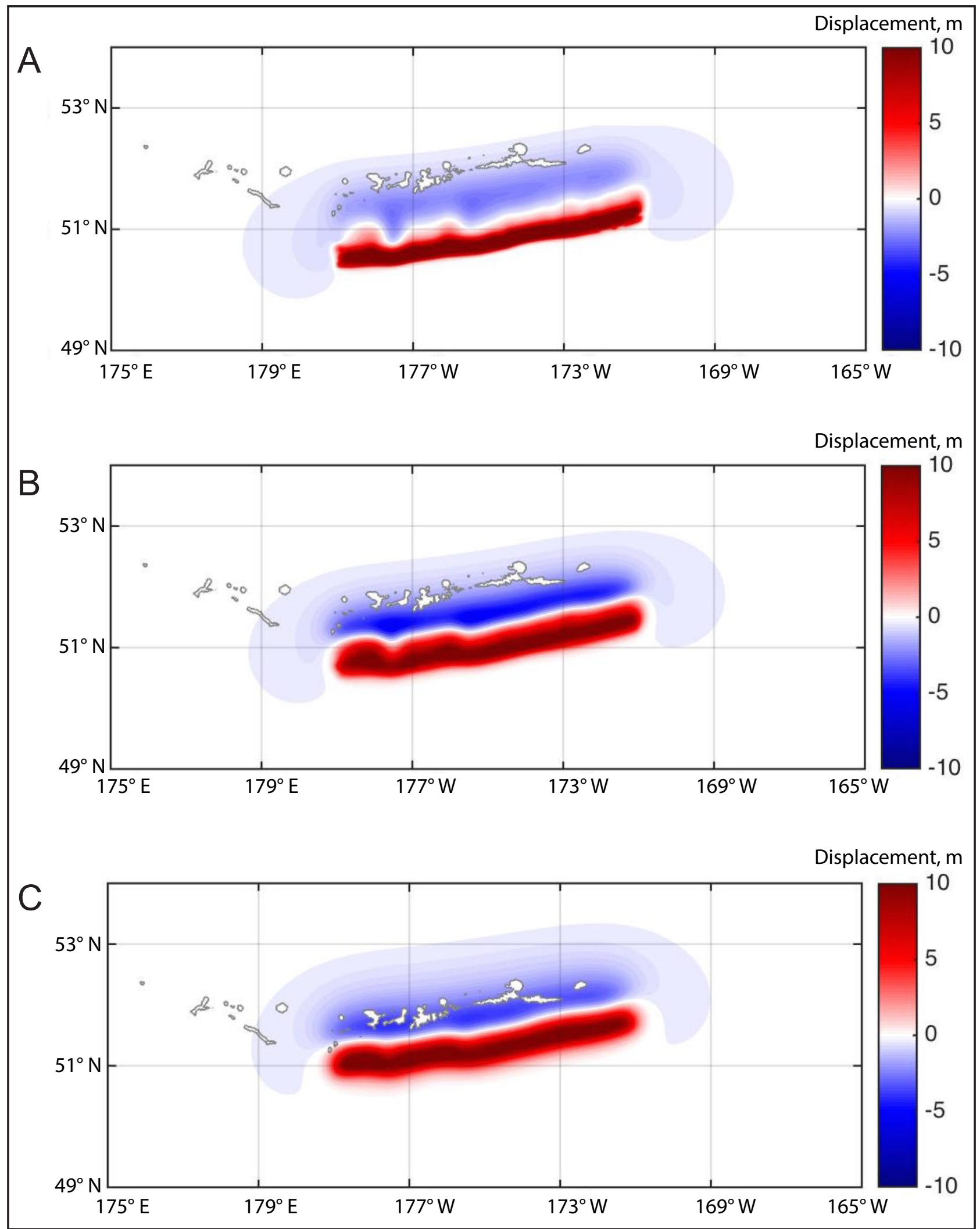

Figure 4. Vertical coseismic deformations corresponding to scenarios 1-3. Blue areas are associated with coseismic ground subsidence; areas of uplift are shown in red. 


\section{Numerical Model of Tsunami Propagation and Runup}

The numerical model currently used by the Alaska Earthquake Center (AEC) for tsunami inundation mapping is a nonlinear, flux-formulated, shallow-water model (Nicolsky and others, 2011b) that has been validated (NTHMP, 2012) through a set of analytical benchmarks and tested against laboratory and field data (Synolakis and others, 2007). The application of the model to tsunami inundation mapping of Alaska coastal communities, including its assumptions and limitations, is described in a number of previous tsunami reports; see Suleimani and others (2010, 2013, 2015) and Nicolsky and others (2011a, 2013, 2014). In this study, we conduct all model runs using bathymetric data that correspond to the Mean Higher High Water (MHHW) tide level in Adak and Atka.

\section{MODELING RESULTS}

We performed numerical calculations for the three scenarios described above. For each scenario, we modeled the water dynamics for each grid listed in table 2 and computed maximum tsunami wave heights in the level 3 grids for Adak and Atka. Each model run was performed for 6 hours of tsunami propagation to account for all waves in the wave train, as well as for secondary (reflected) waves. Figures 5 and 6 show the maximum tsunami wave heights for scenarios 1-3 for the Adak and Atka grids, respectively. We emphasize here that the tsunami wave heights are calculated offshore and they differ from the runup heights, which are the land elevations reached by the waves. In both regions the highest tsunami amplitudes are present along the Pacific shore of the Andreanof Islands, while the Bering Sea coast experiences smaller waves due to the natural barrier of the island chain.

We show the maximum composite tsunami height for all scenarios, calculated for the vicinity of Adak, in figure 7. In this region (fig. 7), the absolute maximum value of the tsunami height with respect to MHHW is $18 \mathrm{~m} \mathrm{(59} \mathrm{ft);} \mathrm{multi-}$ plied by a safety factor of 1.3 it predicts $23.4 \mathrm{~m}$
(76.8 ft) for the maximum estimated runup height for the community of Adak. We present in figure 8 the maximum composite tsunami height for all scenarios, calculated for the vicinity of Atka. The absolute maximum value of the tsunami height in this region is $23.9 \mathrm{~m}(78.4 \mathrm{ft})$; multiplied by a safety factor of 1.3 it predicts $31.1 \mathrm{~m}(102 \mathrm{ft})$ for the maximum estimated runup height for the community of Atka.

Map sheets 1 and 2 illustrate approximate tsunami hazard maps for the communities of Adak and Atka, respectively, and indicate that most of the buildings and infrastructure in each community are within the potential tsunami inundation zone. For each community, we draw an elevation contour on the community topographic map that corresponds to the maximum estimated runup height. This contour approximates the boundary of the tsunami hazard zone and could be used by emergency planners and public officials as a guideline in tsunami mitigation activities. For Atka (map sheet 2), we used the DCRA elevation dataset based on the digital orthophoto of the community. The closest contour to the maximum runup height of $31.1 \mathrm{~m}(102 \mathrm{ft})$ was at the elevation of 31 $\mathrm{m}(102.55 \mathrm{ft})$ and therefore was extracted as the tsunami hazard boundary. No DCRA elevation data existed for Adak, and therefore we extracted the elevation contour of $23 \mathrm{~m}(78.4 \mathrm{ft})$ from the 3 -arc-second DEM of Adak used in the tsunami modeling process. A reader can refer to the metadata that accompanies the report for more details.

To help emergency managers assess the tsunami hazard in Adak and Atka, we supplement the hazard maps with time series of the modeled water level at a nearshore location in each community. These locations are shown by black triangles in figures 7 and 8 , and the time series plots are shown in figure 9. Zero time corresponds to the time when the earthquake occurs. To compare the height of arriving tsunamis for different scenarios, which result in different values of land subsidence, we use a vertical datum with a zero mark corresponding to the post-earthquake sea level. Figure 9 shows that the tsunami wave heights at Atka are compa- 


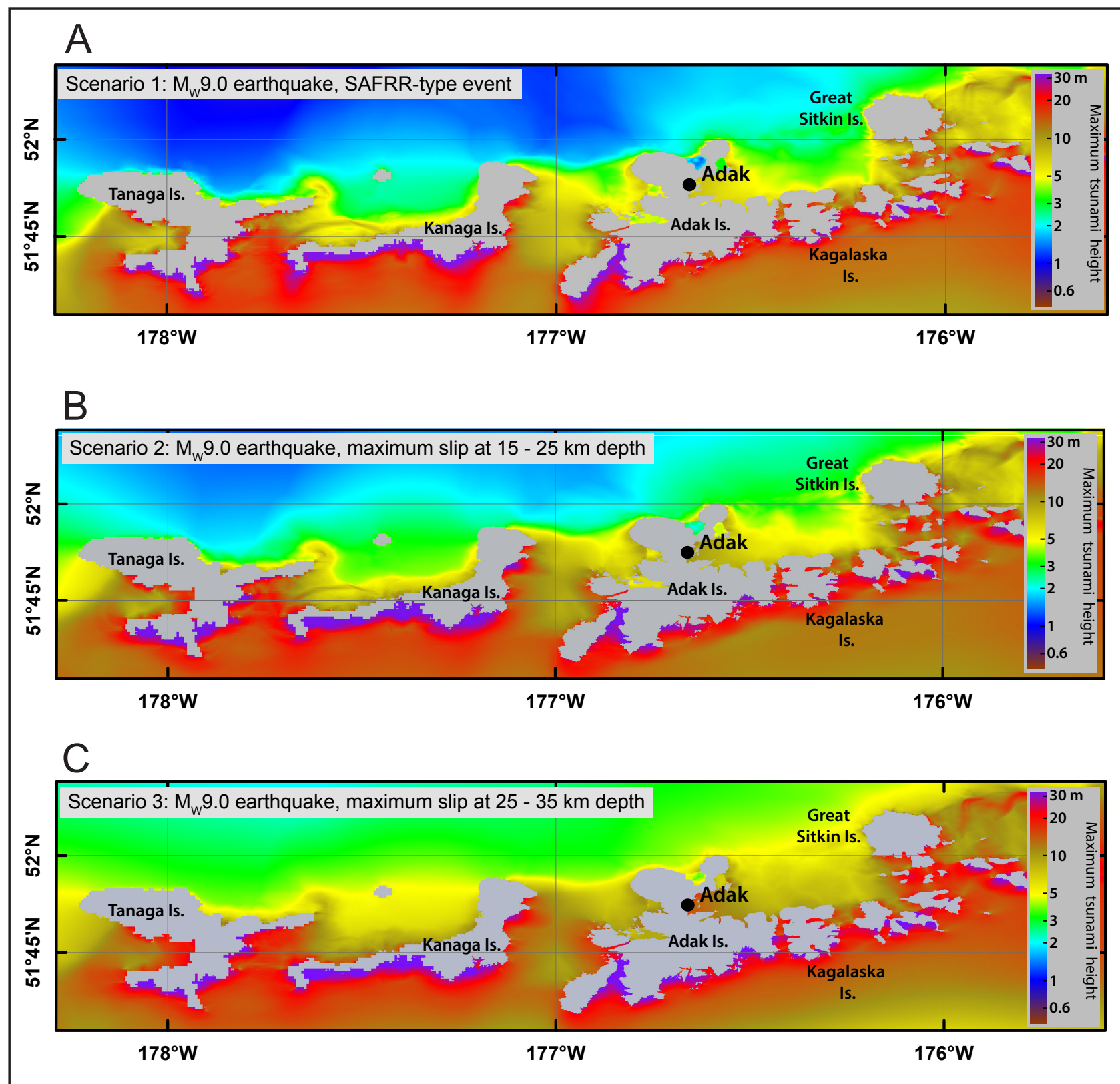

Figure 5. Maximum tsunami wave height for scenarios 1-3 in the level 3 grid for Adak. 


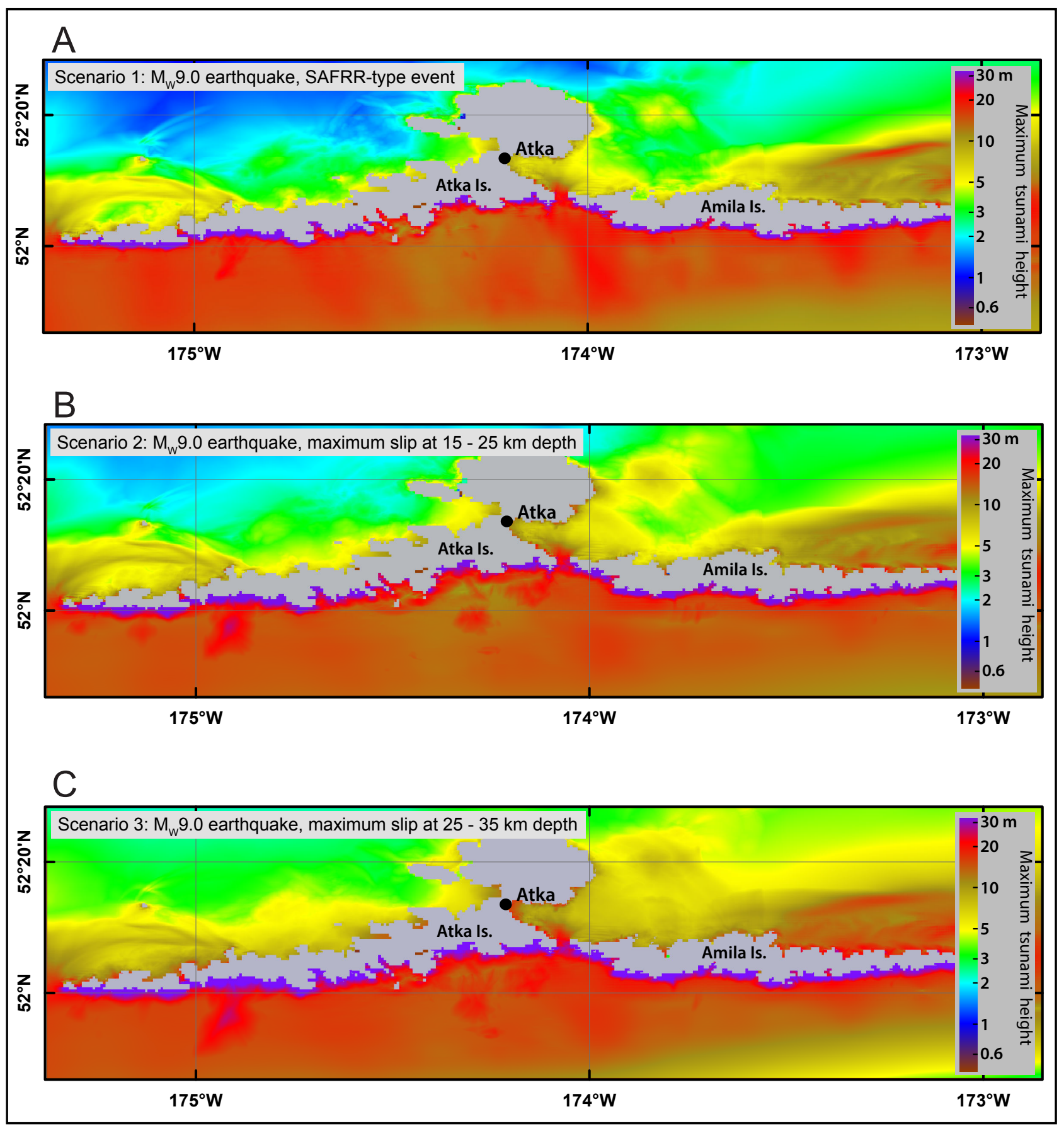

Figure 6. Maximum tsunami wave height for scenarios 1-3 in the level 3 grid for Atka. 


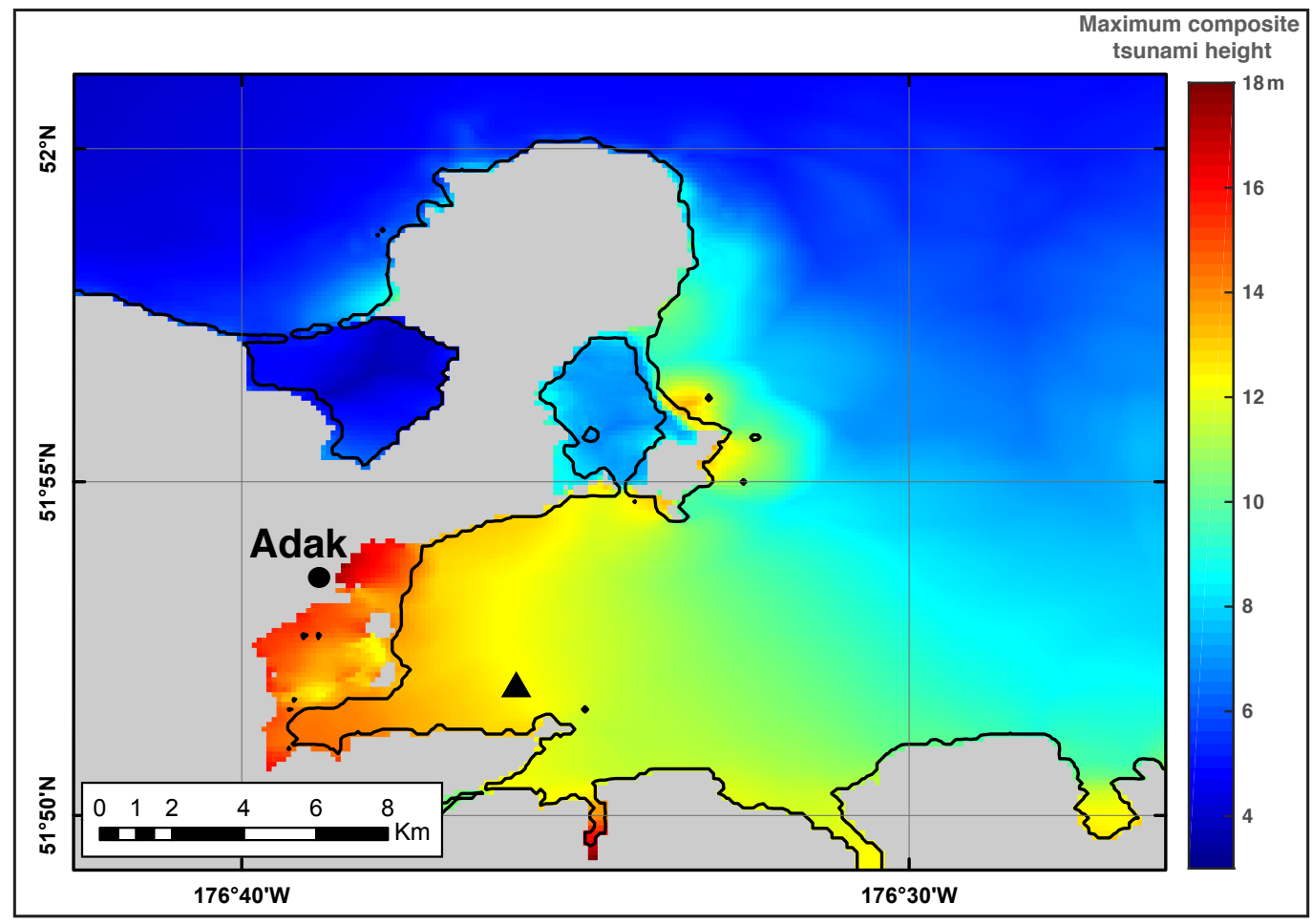

Figure 7. Maximum composite tsunami wave height at Adak. The black triangle indicates the location of the time series point, and the black line is the MHHW shoreline.

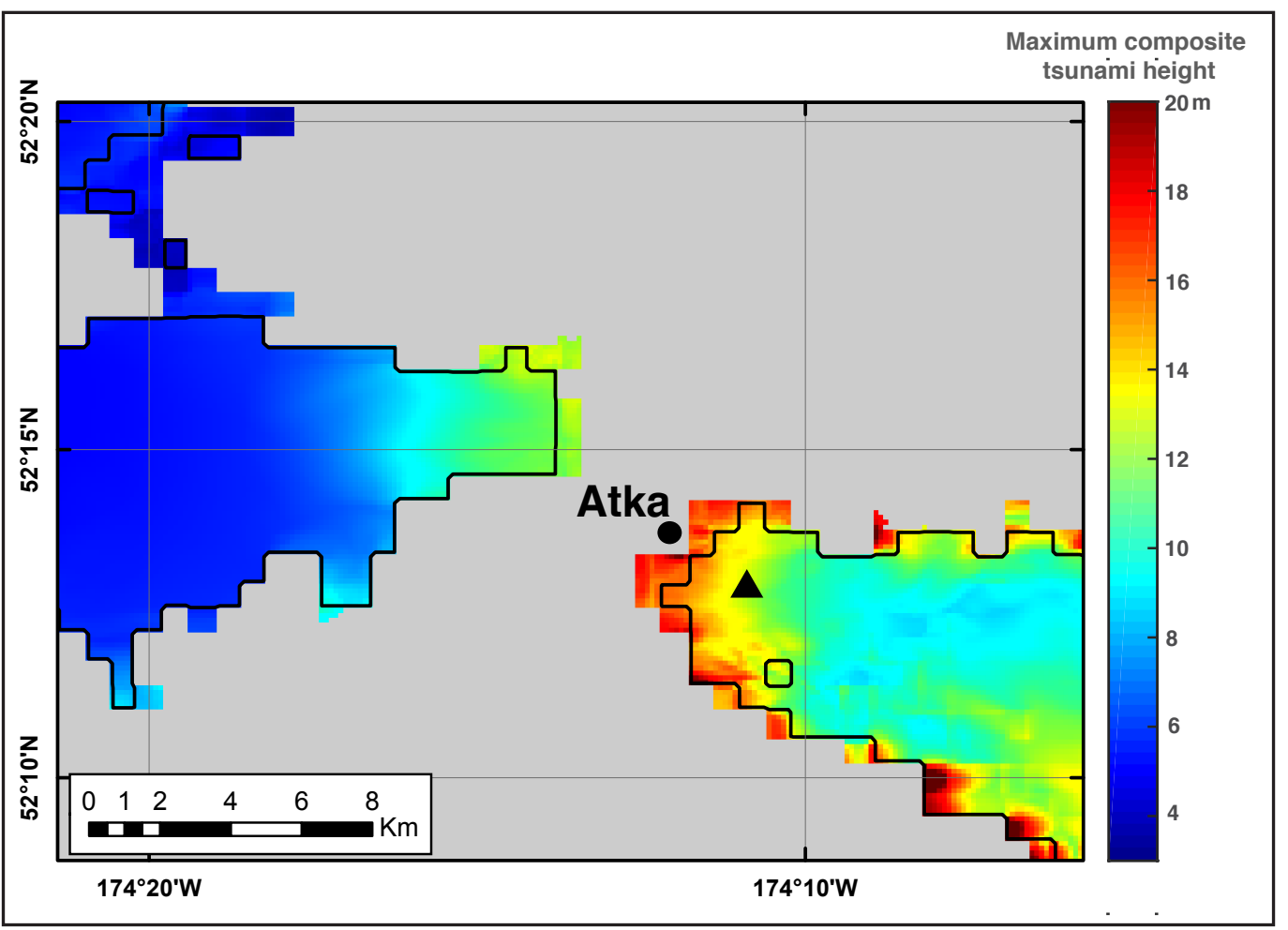

Figure 8. Maximum composite tsunami wave height at Atka. The black triangle indicates the location of the time series point, and the black line is the MHHW shoreline. The low resolution of the shoreline is an artifact of the original level 3 grid for Atka, which was developed by NCEl and had a low-resolution coastline. 


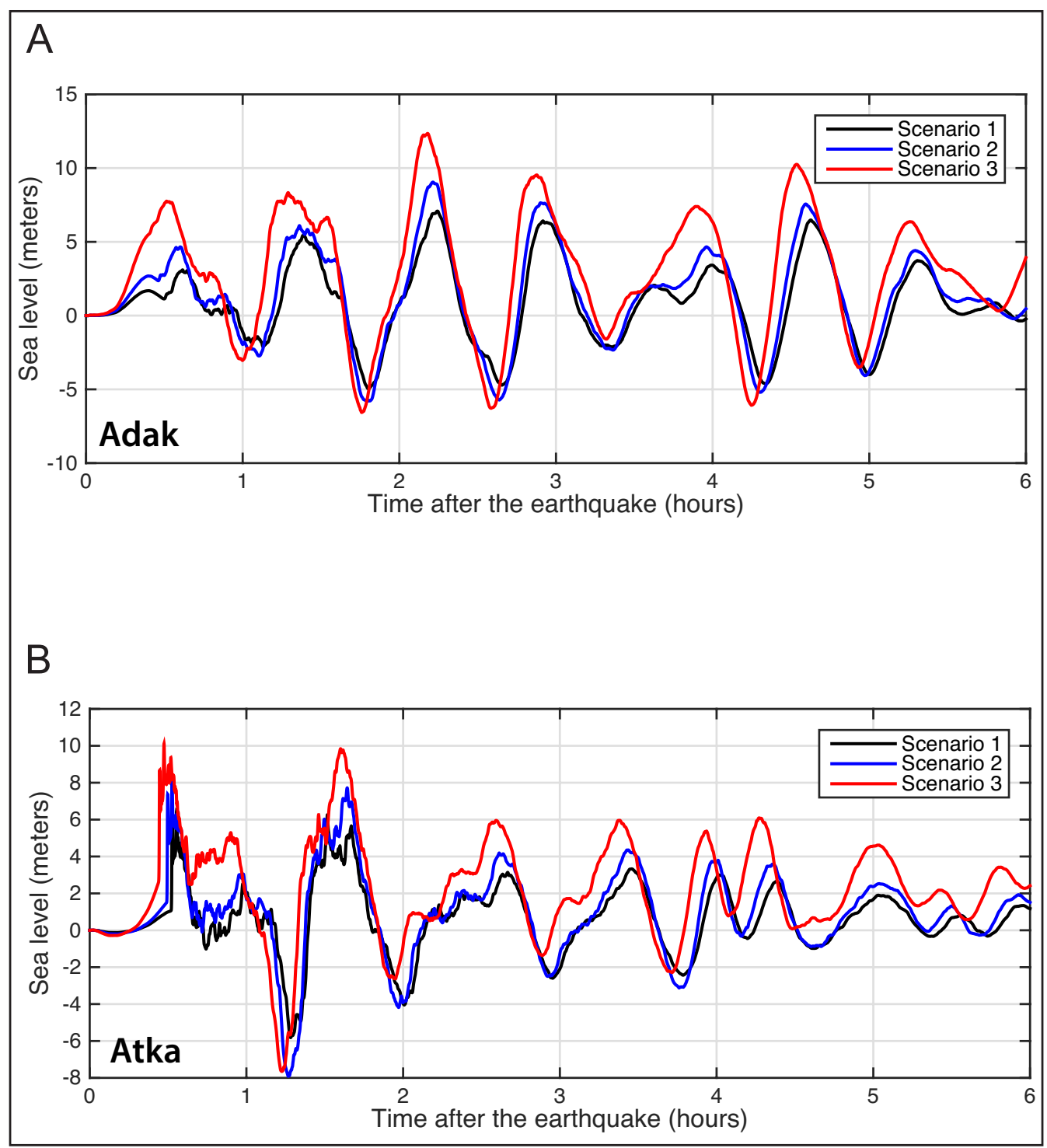

Figure 9. Time series of water level for scenarios 1-3 at Adak (A) and Atka (B) calculated at the locations shown as black triangles in figures 7 and 8 .

rable to the observed water levels during the 1957 tsunami (table 1), while at Adak the simulated tsunami wave heights are much higher than anything recorded. Analysis of the time series plots shows that scenario 3 results in the highest waves at both locations. Also, the time series plots demonstrate that waves of dangerously high amplitudes might be arriving for at least 6 hours.

In addition to the time series of the simulated water level, we have also modeled the potential permanent subsidence in Adak and Atka. The yellow line in map sheets 1 and 2 shows the post-earthquake MHHW shoreline after ground subsidence in Adak and Atka, respectively. Scenario 3 results in the maximum subsidence of $2.9 \mathrm{~m}(9.5 \mathrm{ft})$ in Adak and $2.3 \mathrm{~m}(7.5 \mathrm{ft})$ in Atka (table 3). Most low-lying areas in Adak could be permanently flooded as a result of this hypothetical earthquake, while the permanently flooded area in Atka includes only a narrow band of land along the shoreline.

\section{SUMMARY}

We present the results of modeling earthquake-generated tsunamis in the Andreanof 
Islands region, Alaska, and their effects on the communities of Adak and Atka. We numerically model tsunami waves generated by local hypothetical tectonic sources, analyze tsunami-wave dynamics in the vicinity of the communities, and develop tsunami hazard maps. Specifically, we compute the composite maximum wave height from all considered scenarios and follow the NTHMP guidelines to extrapolate the modeling data on land for estimation of tsunami inundation. The maximum estimated runup heights that include the recommended safety factor are

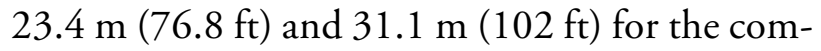
munities of Adak and Atka, respectively.

The tsunami inundation approximations shown on the tsunami hazard maps have been completed using the best information available and are believed to be accurate; however, their preparation required many assumptions. In this assessment, we estimate the potential tsunami inundation zone based on three significant tsunami scenarios. Although the modeled tsunami inundation cannot be considered exhaustive, the modeling results are still thought to provide a sound approximation to the potential tsunami inundation zone in the communities. Note that actual conditions during a tsunami event may vary from those considered, so the accuracy cannot be guaranteed. The limits of inundation shown should be used only as a guideline for emergency planning and response action. Actual areas inundated will depend on specifics of earth deformation, land construction, and tide level, and may differ from areas shown on the map. The information on the hazard maps is intended to assist state and local agencies in planning emergency evacuation and tsunami response actions in the event of a major tsunamigenic earthquake. These results are not intended for land-use regulation or building-code development.

\section{ACKNOWLEDGMENTS}

This project, which is part of the National Tsunami Hazard Mitigation Program (NTHMP), received support from the National Oceanic and Atmospheric Administration (NOAA) under Reimbursable Services Agreement ADN 952011 with the State of Alaska's Division of Homeland Security \& Emergency Management (a division of the Department of Military and Veterans Affairs). Numerical calculations for this work were supported by a grant of High Performance Computing (HPC) resources from the Arctic Region Supercomputing Center (ARSC) at the University of Alaska Fairbanks. We thank Peter Haeussler and Ahmet Yalciner for their reviews that helped to improve the report. We are grateful to Jeff Freymueller for his helpful suggestions and review of potential tsunami sources. 


\section{REFERENCES}

Alaska Department of Commerce, Community and Economic Development Division of Community and Regional Affairs (DCCED/DCRA), 2013, Adak Community Profile. https://www. commerce.alaska.gov/dcra/DCRAExternal/ community/Details/3f694e33-bff6-4cb8-a46860cb72e9f571

Alaska Department of Commerce, Community and Economic Development, Division of Community and Regional Affairs (DCCED/DCRA), 2013, Atka Community Profile. https://www. commerce.alaska.gov/dcra/DCRAExternal/ community/Details/1416bd82-ae8b-413c-a12c5c56c233e3e3

Applied Technology Council, 2012, Guidelines for design of structures for vertical evacuation from tsunamis, second edition: Redwood City, CA, Applied Technology Council Technical Report FEMA P-646, prepared for Federal Emergency Management Agency (FEMA) National Earthquake Hazard Reduction Program (NEHRP) and National Oceanic and Atmospheric Administration (NOAA) National Tsunami Hazard Mitigation Program (NTHMP). https:/www.fema. gov/media-library/assets/documents/14708

Butler, Rhett, 2014, Great Aleutian tsunamis: Honolulu, HI, University of Hawai'i at Manoa, Hawai'i Institute of Geophysics \& Planetology, Peer-Reviewed Report HIGP-2014-1, 170 p., www.higp.hawaii.edu/reports/2014

Carignan, K.S., Taylor, L.A., Eakins, B.W., Warnken, R.R., Medley, P.R., and Lim, E., 2009, Digital elevation model of Adak, Alaska-Procedures, data sources and analysis: National Oceanic and Atmospheric Administration Technical Memorandum NESDIS NGDC-31, U.S. Dept. of Commerce, Boulder, CO, 29 p. http://www. ngdc.noaa.gov/dem/squareCellGrid/down$\operatorname{load} / 258$

Cross, R.S., and Freymueller, J.T., 2007, Plate coupling variation and block translation in the Andreanof segment of the Aleutian arc determined by subduction zone modeling using GPS data: Geophysical Research Letters, Solid Earth, v. 34, no. 6, L06304. http://doi.org/10.1029/2006GL028970
Dunbar, P.K., and Weaver, C.S., 2008, U.S. states and territories national tsunami hazard assessment-Historical record and sources for waves: Technical Report, National Oceanic and Atmospheric Administration and U.S. Geological Survey, 59 p. http://nthmp.tsunami.gov/documents/Tsunami_Assessment_Final.pdf

Estabrook, C.H., Jacob, K.H., and Sykes, L.R., 1994, Body wave and surface wave analysis of large and great earthquakes along the eastern Aleutian arc, 1923-1993-Implications for future events: Journal of Geophysical Research, v. 99, no. B6, p. 11,643-11,662. http://doi. org/10.1029/93JB03124

Freund, L.B., and Barnett, D.M., 1976, A two-dimensional analysis of surface deformation due to dip-slip faulting: Bulletin of the Seismological Society of America, v. 66, no. 3, p. 667-675.

Friday, D.Z., Taylor, L.A., Eakins, B.W., Carignan, K.S., Caldwell, R.J., Grothe, P.R., and Lim, E., 2011, Digital elevation model of Atka, AlaskaProcedures, data sources and analysis: Boulder, CO, U.S. Department of Commerce, NOAA Technical Memorandum NESDIS NGDC-48, 20 p. http://www.ngdc.noaa.gov/dem/squareCellGrid/download/252

Fujii, Yushiro, Satake, Kenji, Sakai, Shin'ichi, Shinohara, Masanao, and Kanazawa, Toshihiko, 2011, Tsunami source of the 2011 off the Pacific coast of Tohoku earthquake: Earth Planets Space, v. 63, p. 815-820. http://doi.org/10.5047/ eps.2011.06.010

Geist, E.L., and Parsons, Tom, 2006, Probabilistic analysis of tsunami hazards: Natural Hazards, v. 37, no. 3, p. 277-314. http://doi.org/10.1007/ s11069-005-4646-Z

Hayes, G.P., Wald, D.J., and Johnson, R.L., 2012, Slab1.0-A three-dimensional model of global subduction zone geometries: Journal of Geophysical Research, v. 117, no. B1, 1 p. http://doi. org/10.1029/2011JB008524

Johnson, J.M., and Satake, Kenji, 1993, Source parameters of the 1957 Aleutian earthquake from tsunami waveforms: Geophysical Research Letters, v. 20, no. 14 , p. 1,487-1,490. http://doi. org/10.1029/93GL01217 
Johnson, J.M., Tanioka, Yuichiro, Ruff, L.J., Satake, Kenji, Kanamori, Hiroo, and Sykes, L.R., 1994, The 1957 great Aleutian earthquake: Pure and Applied Geophysics, v. 142, no. 1, p. 3-28. http://doi.org/10.1007/BF00875966

Kanamori, Hiroo, 1970, The Alaska earthquake of 1964-Radiation of long-period surface waves and source mechanism: Journal of Geophysical Research, v. 75, no. 26, p. 5,029-5,040. http:// doi.org/10.1029/JB075i026p05029

Kirby, Stephen, Scholl, David, von Huene, Roland, and Wells, Ray, 2013, Alaska earthquake source for the SAFRR tsunami scenario, chapter B, in Ross, S.L., and Jones, L.M., eds., The SAFRR (Science Application for Risk Reduction) Tsunami Scenario: U.S. Geological Survey Open-File Report 2013-1170, 40 p. http:// pubs.usgs.gov/of/2013/1170/b/

Lander, J.F., 1996, Tsunamis affecting Alaska, 1737-1996: Boulder, CO, National Oceanic and Atmospheric Administration (NOAA), National Geophysical Data Center (NGDC), Key to Geophysical Research Documentation, v. 31, 190 p. ftp://ftp.ngdc.noaa.gov/hazards/publications/Kgrd-31.pdf

Lim, E., Eakins, B.W., and Wigley, R., 2011, Coastal relief model of southern Alaska-Procedures, data sources and analysis: National Oceanic and Atmospheric Administration (NOAA) Technical Memorandum NESDIS NGDC-43, 22 p. docs.lib.noaa.gov/noaa_documents/NESDIS/NGDC/TM/NOAA_TM_ NESDIS_NGDC_43.pdf

Lopez, A.M., and Okal, E.A., 2006, A seismological reassessment of the source of the 1946 Aleutian 'tsunami' earthquake: Geophysical Journal International, v. 165 , no. 3, p. 835-849. http:// doi.org/10.1111/j.1365-246X.2006.02899.x

National Centers for Environmental Information (NCEI)/World Data Service (WDS), in progress, Global historical tsunami database at NGDC, 2100 BC to present (interactive map): National Geophysical Data Center, NOAA. http://doi.org/10.7289/V5PN93H7
National Tsunami Hazard Mapping Program (NTHMP), 2010, Guidelines and best practices for tsunami inundation modeling for evacuation planning: National Oceanic and Atmospheric Administration (NOAA), NTHMP Mapping \& Modeling Subcommittee. http:// nws.weather.gov/nthmp/mapping_subcommittee.html

2012, Proceedings and results of the 2011 NTHMP Model Benchmarking Workshop: Boulder, CO, U.S. Department of Commercel NOAA/NTHMP, NOAA Special Report, 436 p. http://nthmp.tsunami.gov

Nicolsky, D.J., Suleimani, E.N., Combellick, R.A., and Hansen, R.A., 2011a, Tsunami inundation maps of Whittier and western Passage Canal, Alaska: Alaska Division of Geological \& Geophysical Surveys Report of Investigation 2011-7, 65 p. http://doi.org/10.14509/23244

Nicolsky, D.J., Suleimani, E.N., Haeussler, P.J., Ryan, H.F., Koehler, R.D., Combellick, R.A., and Hansen, R.A., 2013, Tsunami inundation maps of Port Valdez, Alaska: Alaska Division of Geological \& Geophysical Surveys Report of Investigation 2013-1, 77 p., 1 sheet, scale 1:12,500. http://doi.org/10.14509/25055

Nicolsky, D.J., Suleimani, E.N., and Hansen, R.A., 2011b, Validation and verification of a numerical model for tsunami propagation and runup: Pure and Applied Geophysics, v. 168, p. 1,199-1,222. http://doi.org/10.1007/s00024010-0231-9

Nicolsky, D.J., Suleimani, E.N., and Koehler, R.D., 2014, Tsunami inundation maps of Cordova and Tatitlek, Alaska: Alaska Division of Geological \& Geophysical Surveys Report of Investigation 2014-1, 49 p. http://doi. org/10.14509/27241

Nicolsky, D.J., Suleimani, E.N., Freymueller, J.T., and Koehler, R.D., 2015, Tsunami inundation maps of Fox Islands communities, including Dutch Harbor and Akutan, Alaska: Alaska Division of Geological \& Geophysical Surveys Report of Investigation 2015-5, 67 p., 2 sheets, scale 1:12,500. http://doi.org/10.14509/29414 
Ross, S.L., Jones, L.M., Miller, Kevin, Porter, K.A., Wein, A., Wilson, R.I., Bahng, B., Barberopoulou, A., Borrero, J.C., Brosnan, D.M., Bwarie, J.T., Geist, E.L., Johnson, L.A., Kirby, S.H., Knight, W.R., Long, K., Lynett, P., Mortensen, C.E., Nicolsky, D.J., Perry, S.C., Plumlee, G.S., Real, C.R., Ryan, K., Suleimani, E.N., Thio, H.K., Titov, V.V., Whitmore, P.M. and Wood, N.J., 2013, SAFRR (Science Application for Risk Reduction) Tsunami Scenario-Chapter A, Executive Summary and Introduction, in Ross, S.L., and Jones, L.M., eds., The SAFRR Tsunami Scenario: U.S. Geological Survey Open-File Report 2013-1170, p. 1-17. http://pubs.usgs.gov/of/2013/1170/

Shao, Guangfu, Li, Xiangyu, Ji, Chen, and Maeda, Takahiro, 2011, Focal mechanism and slip history of $2011 \mathrm{M}_{\mathrm{w}} 9.1$ off the Pacific coast of Tohoku earthquake, constrained with teleseismic body and surface waves: Earth Planets Space, v. 63, no. 7, p. 559-564. http://doi.org/10.5047/ eps.2011.06.028

Suleimani, E.N., Nicolsky, D.J., West, D.A., Combellick, R.A., and Hansen, R.A., 2010, Tsunami inundation maps of Seward and Northern Resurrection Bay, Alaska: Alaska Division of Geological \& Geophysical Surveys Report of Investigation 2010-1, 47 p., 3 sheets, scale 1:12,500. http://doi.org/10.14509/21001

Suleimani, E.N., Nicolsky, D.J., and Koehler, R.D., 2013, Tsunami inundation maps of Sitka, Alaska: Alaska Division of Geological \& Geophysical Surveys Report of Investigation 2013-
3, 76 p., 1 sheet, scale 1:250,000. http://doi. org $/ 10.14509 / 26671$

Suleimani, E.N., Nicolsky, D.J., and Koehler, R.D., 2015, Tsunami inundation maps of Elfin Cove, Gustavus, and Hoonah, Alaska: Alaska Division of Geological \& Geophysical Surveys Report of Investigation 2015-1, 79 p. http:// doi.org/10.14509/29404

Suleimani, E.N., Nicolsky, D.J., Koehler, R.D., Freymueller, J.T., and Macpherson, A.E., 2016, Tsunami inundation maps for King Cove and Cold Bay communities, Alaska: Alaska Division of Geological \& Geophysical Surveys Report of Investigation 2016-1, 73 p., 2 sheets, scale 1:12,500. http://doi.org/10.14509/29565

Synolakis, C.E., Bernard, E.N., Titov, V.V., Kânoğlu, U., and González, F.I., 2007, Standards, criteria, and procedures for NOAA evaluation of tsunami numerical models: Seattle, WA, NOAA/Pacific Marine Environmental Laboratory, Technical Memorandum OAR PMEL-135, 55 p. http:/www.pmel.noaa.gov/ pubs/PDF/syno3053/syno3053.pdf

Tanioka, Yuichiro, and Gonzales, F.I., 1998, The Aleutian earthquake of June 10, 1996 ( M $\left._{\mathrm{w}} 7.9\right)$ ruptured parts of both the Andreanof and Delarof segments: Geophysical Research Letters, v. 25 , no. 12 , p. 2,245-2,248. http://doi. org/10.1029/98GL01578

Wu, F.T., and Kanamori, Hiroo, 1973, Source mechanism of February 4, 1965, Rat Island earthquake: Journal of Geophysical Research, v. 78, no. 26, p. 6,082-6,092. http://doi. org/10.1029/JB078i026p06082 